\title{
Literature review: Challenging HIV-related stigma and discrimination in Southeast Asia: Past successes and future priorities
}

Joanna Busza

Follow this and additional works at: https://knowledgecommons.popcouncil.org/departments_sbsr-hiv

Part of the Demography, Population, and Ecology Commons, International Public Health Commons, and the Public Health Education and Promotion Commons How does access to this work benefit you? Let us know!

\section{Recommended Citation}

Busza, Joanna. 1999. "Literature review: Challenging HIV-related stigma and discrimination in Southeast Asia: Past successes and future priorities," Horizons Report. Washington, DC: Population Council. 


$$
8
$$


Literature Review:

Challenging HIV-Related Stigma and Discrimination in

Southeast Asia:

Past Successes and Future Priorities

Joanna Busza, M.Sc.

Research Fellow, Population Council/Thailand

\section{(2) Population Council H $\mathrm{X}^{\text {rizons }}$}

This publication was made possible through support provided by the Office of Health and Nutrition, Global Bureau, U.S. Agency for International Development, under the terms of Grant No. HRN-A-00-97-0001200 . The opinions expressed herein are those of the author and do not necessarily reflect the views of the U.S. Agency for International Development. 
The Population Council is an international, nonprofit, nongovernmental institution that seeks to improve the wellbeing and reproductive health of current and future generations around the world and to help achieve a humane, equitable, and sustainable balance between people and resources. The Council conducts biomedical, social science, and public health research and helps build research capacities in developing countries. Established in 1952, the Council is governed by an international board of trustees. Its New York headquarters supports a global network of regional and country offices.

Copyright (@ 1999 The Population Council Inc. 


\section{Contents}

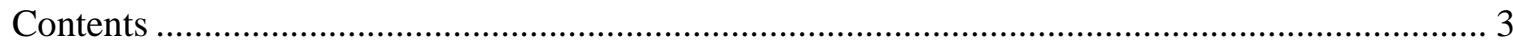

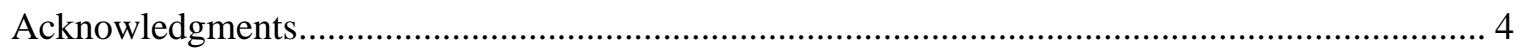

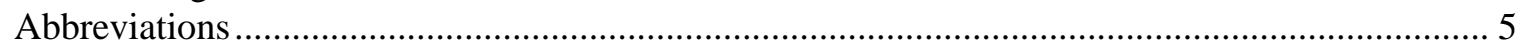

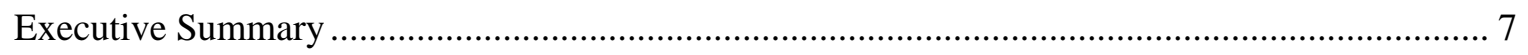

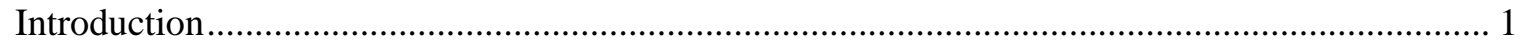

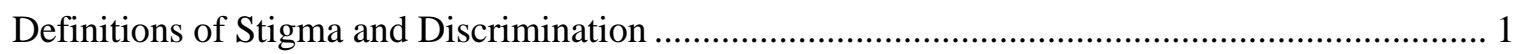

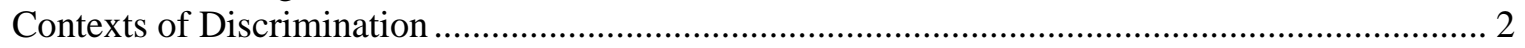

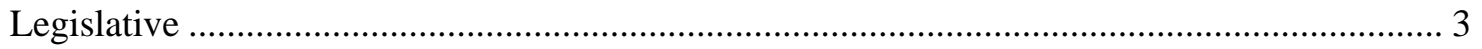

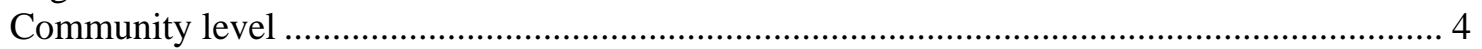

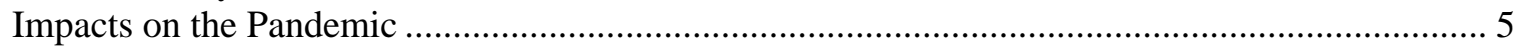

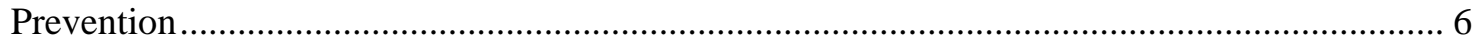

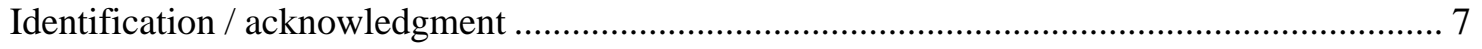

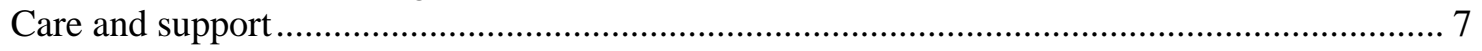

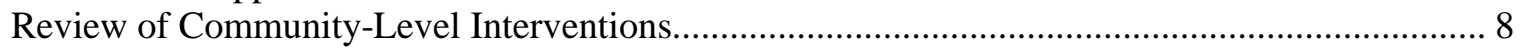

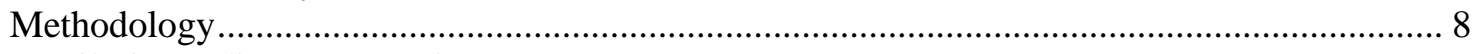

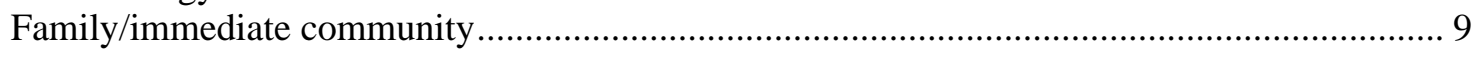

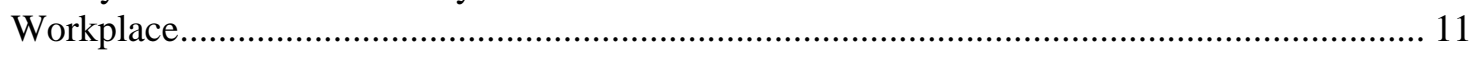

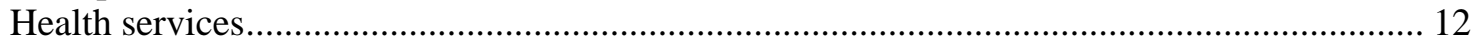

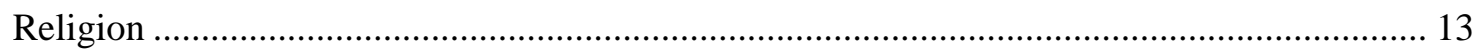

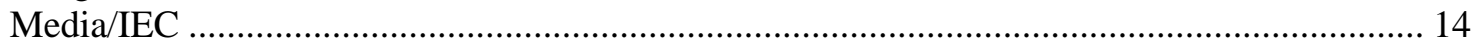

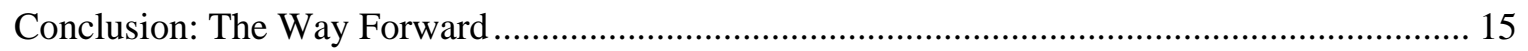

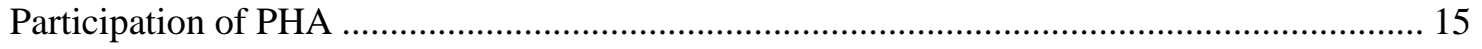

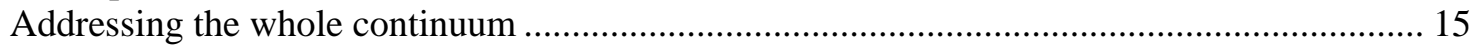

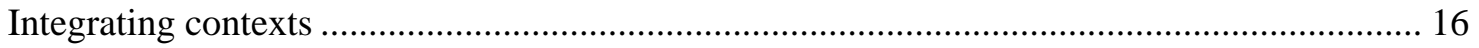

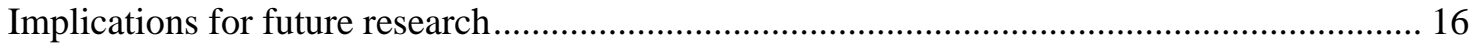

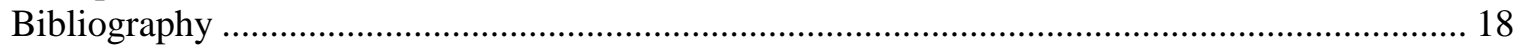




\section{Acknowledgments}

This review was greatly assisted by contributions from the following people. I am grateful for their comments, suggestions, and the generous amount of time they spent discussing projects and ideas with me.

Lori Bollinger, Lisanne Brown, Greg Carl, Marilou Costello, Serge Doussantousse, Daniel Halperin, Ruthy Libatique, Anne Malcolm, Geoff Manthey, Laurie Maund, Gloria Melocoton, Sujaya Misra, Nguyen Viet My Ngoc, Trang Nguyen, Ted Nierras, Susan Paxton, Choo Phuah, Anthony Pramualratana, Runizar Roesin, Abby Ruddick, Chhim Sarath, Tilly Sellers, Joe Selveratnam, Supaporn Thinwatanangkul, Joe Thomas, Brett White, Khim Chong Yee. 


\section{Abbreviations}

AIDS Acquired Immunodeficiency Syndrome

$\mathrm{APN}+$

Asia Pacific Network of People Living with HIV/AIDS

FARM Foundation for Agricultural and Rural Management

HIV Human Immunodeficiency Virus

IDU Injecting drug users

IEC Information, education, and communication

KHANA Khmer HIV/AIDS NGO Alliance

MBCA Malaysian Business Coalition on AIDS

MSM Men who have sex with men

NGO Nongovernmental organizations

PHA People living with HIV/AIDS

STI Sexually transmitted infections

SW Sex worker

TBCA Thai Business Coalition on AIDS

YPI

Yayasan Pelita Ilmu (Light of Science Foundation) 


\section{Executive Summary}

Pervasive stigma has surrounded HIV/AIDS since the beginning of the pandemic. In Southeast Asia, as elsewhere, it has been accompanied by discrimination, affecting transmission patterns and access to care and support. This paper describes the regional experience of stigma and discriminations and offers a review of community-based interventions that have attempted to reduce them. The evidence presented comes primarily from unpublished literature and anecdotal evidence gained through interviews with project staff throughout the region.

The response to HIV/AIDS is increasingly conceptualized as a continuum between prevention and care, and the effects of stigma and discrimination can also be framed within this model. Ideally, people seek counseling and testing to identify their HIV status without fear of repercussions. Those who test positive then receive available care, and are encouraged to change their behaviors to protect others from infection. Their communities can support people living with HIV/AIDS (PHA), and their integration into society personalizes the risk to others, aiding prevention efforts. A stigmatizing social environment, however, poses barriers at all stages of this cycle. People fear discrimination and thus refrain from seeking testing. Identified PHA may receive substandard treatment, and may refuse to disclose their status to partners or change their behavior to avoid negative reactions. They thus do not seek care and support, nor do they contribute to reducing future transmission. These reactions hamper the efforts of HIV/AIDS interventions.

Stigma and discrimination can be challenged, however. Although one way to reduce their impact is at the legislative level, the focus of this review is on community-based interventions. These projects target stigmatization manifested in a wide range of community contexts, including: family and immediate community, workplace, health services, religion, and the media. The interventions described tend not to be "stigma and discrimination projects" as such but rather limit negative attitudes as a "side effect" of other goals through innovative approaches. Although these activities represent initiatives in a number of both countries and contexts of discrimination, they nonetheless share certain components worth highlighting. What these characteristics have in common is an emphasis on process, indicating that reducing community-level discrimination can be integrated into any approach to HIV/AIDS:

- Participation of PHA: When PHA are brought to the forefront of the response and are involved at all stages of an intervention, they demonstrate their ability to remain productive members of their community. They reduce both felt and enacted stigma by "normalizing" and personalizing the experience of HIV/AIDS. Encouraging and nurturing PHA networks and participation, therefore, are crucial first steps for projects to take.

* Addressing the whole continuum: Because prevention and care are linked, reducing HIVrelated stigma and discrimination must take these links into consideration. The projects reviewed take a holistic view of the barriers posed through discrimination, and incorporate activities that draw attention to prevention, care, and support aspects of the HIV experience in a community.

* Integrating contexts: As individuals are members of many "communities" throughout their lives, successful interventions also target more than one context of discrimination.

Throughout the region, projects have been strengthened by building alliances between various segments of civil society. Such a comprehensive approach promotes sustainability and expands the scope of contributions to the response.

Finally, significantly more data are needed in order to better understand the exact mechanisms that work to reduce stigma and discrimination. Specific indicators should be developed and subsequently integrated into projects to help refine interventions. What is clear, however, is that through surveying the available programmatic literature and anecdotal evidence, lessons from the past can help illuminate the way forward in this important area. 


\section{Introduction}

Sexually transmitted infections have always been imbued with stigma due to their association with behaviors considered deviant or immoral (Goldin 1994). Similarly, societies have historically reacted with fear to disfiguring, debilitating, and fatal diseases and have translated this aversion into discriminatory actions against the infected (Alonzo et al. 1995). The HIV/AIDS pandemic has presented the world with a condition that combines these characteristics - and it has frequently been met with stigma and discrimination, a reaction dubbed "the second epidemic" (Somerville and Orkin 1989).

Yet despite the widespread attachment of stigma to people infected or affected by HIV/AIDS, the experience of discrimination has not been constant or consistent across time or place. As with many natural phenomena, societies have " ... their own meanings and explanations for sickness, ideas about disease transmission and sexual behaviour. ... Fears associated with illness, disease, and sex therefore need to be viewed in this broader social and cultural context" (Malcolm et al. 1998:351). Regional, national, and cultural differences can and do shape the level and manifestations of HIV-related stigma. Subsequently, the impact of these social responses shapes the wider HIV epidemic itself.

Dynamics of HIV are almost always difficult to disentangle, but clear evidence, even if anecdotal, exists to indicate that both actual discrimination and fear of stigmatization affect transmission patterns and contribute to determining the success or failure of prevention and care and support efforts. Despite a dearth of research on the topic, it is increasingly becoming acknowledged that "effective prevention and treatment strategies require an understanding of cultural frameworks, including of stigmatization" (Goldin 1994:1361).

This is as true in Southeast Asia as elsewhere. Although a large region containing a wide range of cultures, religions, government systems, social structures, and, not least, local HIV epidemics, Southeast Asia allows for a diverse set of lessons to be learned. The opportunities for exchanging experiences have been well established by now. Many epidemiological characteristics of the spread of HIV have been shared between borders, and therefore intervention approaches can also be transferred, adapted, and refined to fit new environments. Interventions that tackle the barriers posed by stigma and discrimination, however, for the most part have remained neglected throughout the region, making it imperative to highlight what has been done and what has worked.

This paper describes stigma and discrimination in Southeast Asia and offers a review of interventions that have attempted to reduce them. The evidence presented comes primarily from unpublished literature, including project reports, internal evaluations, and anecdotal evidence gained through interviews and personal communications. The paper starts with commonly used definitions of both stigma and discrimination as they relate to HIV/AIDS, and outlines the forms and contexts that such discrimination has taken in the region. It then describes their impact on all stages of the epidemic and on the responses of individuals and communities. Using this description as a framework, examples of interventions are described which have in some way worked to reduce stigma and discrimination at the community level. Although few projects have specifically targeted discrimination as their primary aim, many have adopted holistic approaches to tackling HIV that have nonetheless succeeded in reducing the stigma surrounding the infection. Finally, the paper concludes by highlighting the mechanisms that are common to many of the projects reviewed despite the fact that the interventions operate within such different contexts. Ultimately, these components help prioritize areas for future programmatic focus.

\section{Definitions of Stigma and Discrimination}

Stigma generally refers to a negatively perceived defining characteristic, either tangible or intangible. It is an attribute used to set the affected persons or groups apart from the normalized social order, and this separation implies a devaluation (Gilmore and Somerville 1994). In regard to HIV/AIDS, the stigma may be the actual infection or it may be based on behaviors believed to lead to infection. As the global pandemic first received international recognition in populations of 
men who have sex with men (MSM), injection drug users (IDU), and sex workers (SW), these already socially marginalized groups began to face additional stigmatization. In such cases, "... the stigma attached to AIDS as an illness is layered upon preexisting stigma" (Herek and Glunt 1988:887). The association with an incurable disease is then used as medical justification for established patterns of exclusion of groups already deemed morally questionable (McGrath 1992). Conversely, people living with HIV/AIDS (PHA) may become implicitly associated with stigmatized behaviors, regardless of how they actually became infected (Tan and Brown 1994). These pathways of stigma are difficult to disentangle, but mutually reinforce each other (Bunting 1996).

Furthermore, stigma may be applied with varying degrees of force, depending on local moral judgments about means of acquisition (Kegeles et al. 1989). In Southeast Asia, a clear gradient of "guilt" and "innocence" has formed the discourse surrounding HIV/AIDS. Sex workers or IDUs who contract HIV are classified as most guilty, with clients of SW following. At the other end of the spectrum, common wisdom posits monogamous wives infected by their IDU or SW-client husbands as "innocent" and "vulnerable," while their HIV positive children, infected during pregnancy, birth, or breastfeeding become the ultimate "defenseless victims." Varying degrees of stigma are applied to these PHA groups, and often to their family members or immediate communities.

Discrimination is composed of "... the actions or treatment based on the stigma and directed toward the stigmatized...." (Bunting 1996:67). The stigmatized find themselves ostracized, rejected, and shunned (Alonzo et al. 1995) and may experience sanctions, harassment, scapegoating, and even violence based on their infection or association with HIV/AIDS (APN+ 1999; McGrath 1992). Discrimination may spring from social disapproval of the infection and its implied behaviors, or from fears due to lack of knowledge about how HIV/AIDS can or cannot be transmitted. Because the HIV pandemic emerged so suddenly and progressed so quickly, in many countries discrimination could result from people's belief “... that not enough time remains to weigh carefully the strengths and weaknesses of various alternative solutions to an AIDS-related problem" (Herek and Glunt 1988:888) and the reaction is thus to err on the side of caution, even at the expense of individual rights.

Ultimately, however, the concepts of stigma and discrimination are closely linked, and they are frequently referred to together, as throughout this paper. Some authors choose to refer to discrimination as "enacted stigma"(Malcolm et al. 1998). Because discrimination often includes public restrictions and punishing actions, however, it can frequently be more easily identified, and thus will remain separately defined in this review. Furthermore, most of the interventions identified by this paper were developed as reactions to discriminatory actions, and rarely have focused on the more abstract problem of felt stigma. The hope has been that in the process of tackling manifestations of stigma, deeply rooted social attitudes will also be addressed. As the response to HIV/AIDS develops, approaches that more proactively challenge stigmatizing social norms should gain increasing attention.

\section{Contexts of Discrimination}

Since the onset of the HIV epidemic, discrimination has tended to fall into two basic categories: legislative forms of discrimination which reflect stigma that has been officially sanctioned and legitimized through laws or policies; and community-level forms, in which marginalized groups experience discrimination in a variety of less formal contexts, often those related to family and other structures of civil society. Widespread negative attitudes perpetuated through shared social discourse, such as by the media, could be said to constitute a third, societal-level form of discrimination. For the purposes of this paper, however, the influence of pervasive and stigmatizing media images will be considered within the rubric of discrimination at the community-level.

In reality, these forms of discrimination may not be easily delineated. Laws and policies can mirror community beliefs, and civil society operates within institutional norms. As a result, 
interventions that try to reduce discrimination may also blur the distinctions. Advocating for policy change may eventually lead to redressing injustices committed in the community, while working at the grassroots from the start may stimulate popular support for changes at the policy level. In general, however, strategies targeting stigma and discrimination usually focus on either the legislative $o r$ the community level. Although this paper will concentrate on the latter in reference to Southeast Asia, both categories of discrimination are briefly described below, with emphasis on how they reinforce each other.

\section{Legislative}

Forms of legislative discrimination include restrictions on travel, enforced isolation, and mandatory testing and reporting, among others. Many of these disciplinary practices, whether inflicted on PHA or other marginalized groups, have been condemned through international agreements on universal human rights, which are founded on the principles of nondiscrimination (Gruskin, Hendriks, and Tomasevski et al. 1996).

The countries of Southeast Asia, with exceptions, have a good history of ratifying conventions that either explicitly or by extension prohibit discrimination on grounds of a person's HIV/AIDS status (Tan and Brown 1994). As with many such accords, however, what a nation internationally agrees to and how it domestically acts do not always coincide. Furthermore, throughout the region, locating the debate about HIV discrimination within the wider discourse on international human rights has not always advanced the cause of reducing the discrimination. The discussions have often become mired in the perceived "...opposition between Eastern 'values' and liberal Western concepts of human rights" (Stephens et al. 1998: S94). Asian traditional values are frequently characterized as communal, placing the benefits of whole societies over the interests of any one person, while human rights as developed in the West emphasize the freedoms of the individual. Although this dichotomy over-simplifies the complex arguments on both sides, its existence makes common ground on a subject such as legal approaches toward HIV and PHA difficult to find.

Although discussion of how to redress legislative discrimination lies beyond the scope of this review, it is worth mentioning that for the most part, the international community has "... recognized that there is no justification for the restriction of the rights and freedom of people with HIV infection" (Malcolm et al. 1998:353). Removal of discriminatory policies and the establishment of protective legislation provide a useful backdrop for community level interventions. Where legal frameworks exist and monitoring and enforcement processes are impartial and easily accessed, then NGOs and other civil society groups have a firm base from which to mount their challenges to stigma and discrimination in their communities. On the other hand, where widespread human rights abuse, civil unrest, and a lack of democratic structures predominate, discrimination that is specifically targeted at PHA cannot be effectively addressed (Beyrer 1998). 


\section{Community level}

Most people participate in many "communities" either simultaneously or at different times throughout their lives. As a result, to consider social responses to HIV/AIDS at the community level requires scrutiny of numerous contexts. The table below lists community-level contexts where HIV-related discrimination has been experienced in Southeast Asia, and examples of how this discrimination has been manifested.

\begin{tabular}{|c|c|}
\hline $\begin{array}{l}\text { Contexts of Discrimination } \\
\text { (adapted from } \\
\text { Malcolm et al. 1998) }\end{array}$ & Examples \\
\hline $\begin{array}{l}\text { Family/Immediate } \\
\text { community (e.g., village) }\end{array}$ & $\begin{array}{l}\text { - Isolation of both infected and affected due to fears of casual contact } \\
\text { * } \\
\text { * }\end{array}$ \\
\hline Workplace & $\begin{array}{l}\text { Mandatory testing before hiring/refusal to employ } \\
\text { * Involuntary periodic testing/dismissal on grounds of HIV status } \\
\text { * } \quad \text { Refusal to work with infected colleagues out of fear of contagion }\end{array}$ \\
\hline Health Services & $\begin{array}{l}\text { Refusal to treat } \\
\text { Violations of confidentiality } \\
\text { Provision of care in specific establishments (such as STI clinics) that } \\
\text { further stigmatize the client } \\
\text { Behavior with clients that clearly identifies their HIV status, instead of } \\
\text { using universal precautions } \\
\text { Advice given or pressure applied for HIV+ person to undergo treatment } \\
\text { that would not be emphasized for others (e.g., abortion, sterilization). }\end{array}$ \\
\hline Religion & $\begin{array}{l}\text { Denial of traditional rituals e.g. funeral practices; restricted access to } \\
\text { marriage }\end{array}$ \\
\hline Media & $\begin{array}{l}\text { * Demonization by public health campaigns of specified "transmitters" } \\
\text { such as SW, reinforcing division between "guilty" and "innocent" PHA } \\
\text { * Depiction of HIV/AIDS as death, perpetuating fear and anxiety rather } \\
\text { than normalization } \\
\text { * Reinforcement of stereotypical gender roles that perpetuate women's } \\
\text { vulnerability to sexual coercion and HIV infection }\end{array}$ \\
\hline
\end{tabular}

Specific instances of discrimination from a wide variety of Southeast Asian countries are plentiful. In Thailand, recent news reports stated that despite almost a decade of the epidemic and continued public health advocacy, AIDS orphans have been forced to leave their former villages (Bhatiasevi 1999), HIV-positive children are denied entry to schools (Assavanonda 1999), and some hospitals continue to refuse to treat known PHA (Assavanonda and Hutasingh 1999). The persistence of such discrimination in a country known for its successful and rapid response to HIV/AIDS may be a result of "... the style of the early [media] campaigns [which] inadvertently contributed to the widespread social stigmatization and fear of people living with HIV/AIDS" (Ungphakorn and Sittitrai 1994:S155).

Cambodian media campaigns began later than in other countries, and public health officials attempted to avoid using fear as the basis for prevention measures (Misra 1999). As in other countries, however, rejection of HIV-positive people by family, forced isolation from the 
community, and refusal by monks to provide traditional burials for PHA have all occurred, although staff from some outreach projects report that they have noticed less stigmatization than they expected (Phuah 1999; Sellers 1999; Misra 1999).

In Indonesia, families in Bali have been found to separate the household items, clothing, and personal belongings of PHA. Sometimes the entire family has experienced rejection by the wider community (Sarjana, Wiyadnyana, and Kauci 1999). When an NGO in Jakarta attempted to open a support center for PHA, it met with intense neighborhood resistance (Djoerban 1998). Vietnam initially included combatting the HIV/AIDS epidemic in its "Social Evils Campaign" (Da Nang AIDS Committee and World Vision 1998) while in Laos, prevailing conservative attitudes regarding sexuality have led to a situation where a public health response "... may further stigmatise the risk groups selected for surveillance and targeted control measures" (Insisiengmay and Bounlu 1998:154).

Dismissal from work on grounds of serostatus have been noted in Thailand, Singapore, Malaysia, and Indonesia, and in many countries in the region HIV-positive women are strongly pressured to undergo surgical contraception or, if already pregnant, to have abortions (Tan and Brown 1994).

These examples, and most of the information available on HIV-related stigma and discrimination, come from small-scale qualitative assessments or anecdotal evidence from people working in the field. A large gap in the research still exists on this topic. It is worth mentioning, however, that the Asia Pacific Network of People Living with HIV/AIDS (APN+) is launching a project that should help fill this gap. Entitled "Multi-city participatory action research on AIDS and human rights in Asia Pacific region" the initiative will use peer data gathering techniques, and will comprehensively document the nature and scope of HIV-related discrimination and human rights abuses in select Southeast Asian countries (APN+ 1999).

These instances of discrimination, and the fears that they induce, affect the progress of the HIV epidemic in numerous detrimental ways. The rest of this paper is devoted to demonstrating these impacts and exploring how interventions working within the contexts listed can successfully counteract community-level discrimination.

\section{Impacts on the Pandemic}

Effective responses to HIV/AIDS are increasingly framed within a model of a prevention-to-care continuum (MacNeil and Anderson 1998). Prevention reduces the need for future care, of course, but care and support activities also help to normalize and raise awareness of the disease and its transmission routes, encouraging prevention. Care also frequently brings PHA to the forefront of efforts to promote prevention within the community, helping others to perceive that they could be at risk, and encouraging them to seek testing and then adopt safer behaviors (MacNeil and Anderson 1998). This cycle relies on a supportive environment in which individuals feel they will receive help and understanding should they find themselves to be HIV-positive, and in which behavior change is viewed favorably. Stigma and discrimination hinder the creation of such a supportive environment at all stages of the cycle.

Figure 1 illustrates the links between prevention and care, with testing and identification of HIV status being one of the steps within the trajectory. The ways in which stigma and discrimination pose barriers to an appropriate response are also included in the diagram. 
Figure 1. Impacts on the prevention to care continuum

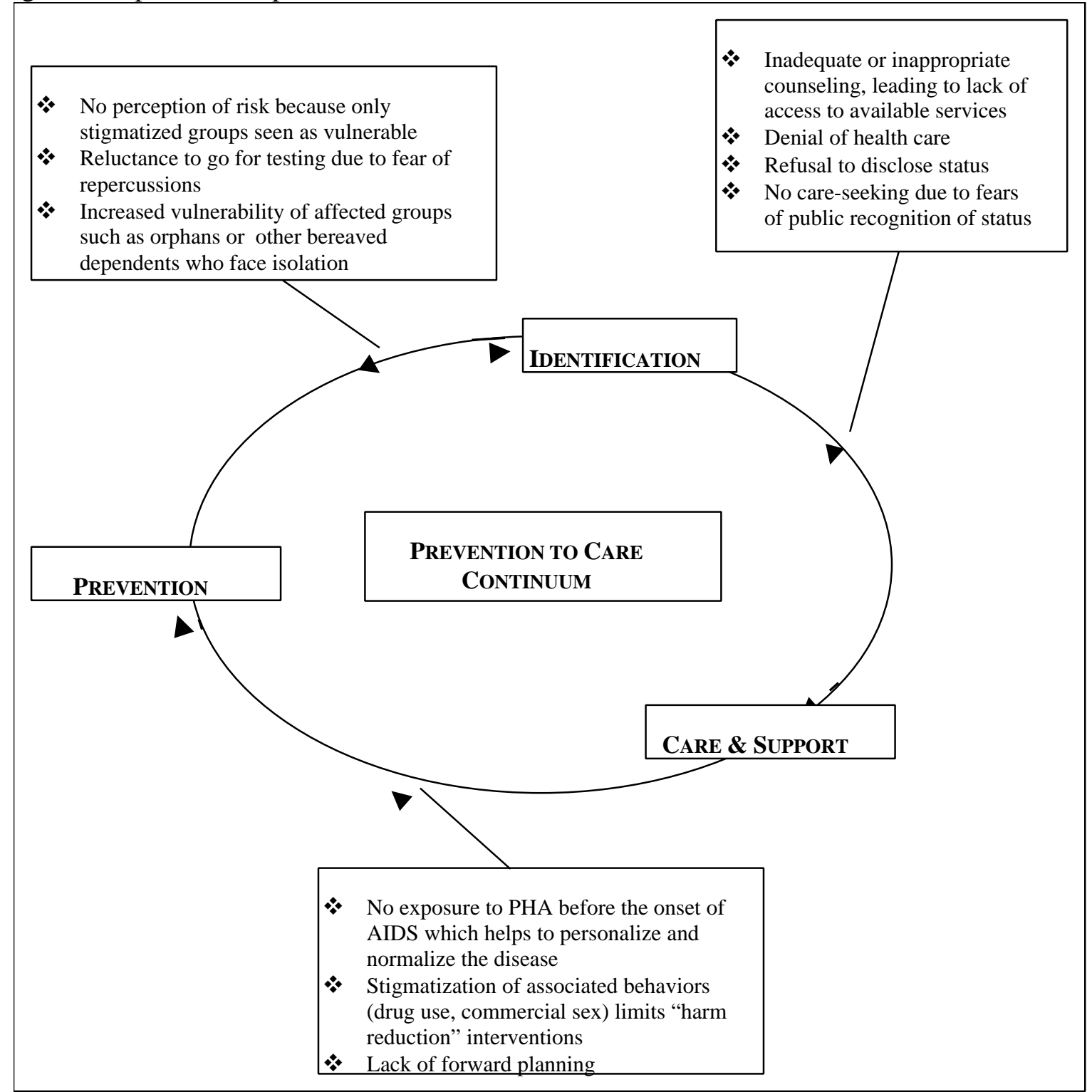

\section{Prevention}

The stigma surrounding HIV has resulted in attempts by people and communities to relieve their fears by perceiving certain "other" groups to be "at risk" rather than considering the possibility of acquisition through their own behaviors (Ungphakorn and Sittitrai 1994). The marginalization of these "risk groups," usually IDUs and SWs, “... poses a serious health threat because it allows individuals to disassociate themselves from the disease by disavowing membership in identified risk groups" (Goldin 1994:1360). When socially distanced from the threat in this way, people are less likely to change their behaviors such as by adopting safer sex practices. Furthermore, if the environment is not favorable to behavior change overall, then simply adopting preventive measures serves as indication of possible infection and invites discrimination.

Testing and counseling have also been shown to aid prevention. For example, people who receive positive test results can take measures to prevent transmission to others and can begin to seek appropriate treatment (De Zoysa et al. 1995; Bentley et al. 1998). It has also been posited that when people receive a negative test result but confront important issues through counseling they will reduce their high-risk behaviors; evidence for this behavior change is mixed and a recent review of testing and counseling studies found no significant effect (Weinhardt et al. 1999). Yet when pervasive stigma and discrimination exist, concerned individuals feel reluctant to be tested 
due to fears of discriminatory repercussions. If s/he realizes that a positive test result will result in isolation, harassment, loss of employment, and denial of health services, for example, then a person fearing that $\mathrm{s} / \mathrm{he}$ may have been infected in the past will prefer to remain in ignorance, especially in circumstances where confidentiality cannot be ensured. The anticipation of “... blame may lead to continued high incidence, as those who are really infected do not come forward, are not identified, and therefore continue to transmit the virus" (McGrath 1992:73). In Thailand, such fears were reduced when mandatory reporting of positive results ceased; subsequently, the establishment of anonymous clinics increased the numbers of people seeking testing (Ungphakorn and Sittitrai 1994; Tan and Brown 1994).

Finally, the stigma surrounding HIV-associated behaviors such as drug use or certain sexual practices also pose barriers to successful prevention. Implementation of "harm reduction" measures such as condom provision for both male and female sex workers, needle exchanges, or detailed sex education for adolescents may prove impossible due to fears that they promote behaviors that remain socially unacceptable (Miller et al. 1990; Beyrer, 1998).

\section{Identification/acknowledgment}

Once identification of HIV infection has occurred, however, health-seeking behavior and planning for the future become possible. Ideally, HIV-positive individuals notify their partners, family, and wider community, adopt safe behaviors to avoid further transmission, and receive care, understanding and support in return. In reality, as illustrated in earlier examples, "persons infected with HIV must bear the burden of societal hostility at a time when they are most in need of social support" (Herek and Glunt 1988:886).

The results are varied and numerous: HIV-infected people do not seek available care options; they are treated disrespectfully or denied services at health care facilities; they receive treatment only at late stages for isolated cases of opportunistic infections rather than being treated holistically with whatever medical and psycho-social care models are locally available; and they are unable to plan for the future with the participation of their dependents and in interaction with their wider communities (Gilmore and Somerville 1994; Gruskin, Hendriks, and Tomasevski 1996; Malcolm et al. 1998).

\section{Care and support}

Stigma and discrimination continue to affect PHA through to the end of their lives, hampering the ability of the community to normalize the disease and integrate it into shared coping strategies as might occur with other terminal illnesses. If care and support mechanisms are not present or people are too afraid to utilize them, communities do not address the issues surrounding HIV, nor are they exposed to PHA before the most debilitating phases of their illness. Not only is this detrimental to PHA, but it interrupts the cycle where care can directly influence future prevention.

PHA who are acknowledged, visible, and accepted in their communities do much to aid ongoing prevention efforts within the community. Not only does familiarity with PHA personalize the risk for others and stimulate behavior change, good care and support programs demonstrate how casual contact with PHA is safe. Experience from throughout the world indicates that "knowing someone with HIV/AIDS can have a strong preventive impact, but when care and support are weak, people tend not to reveal their HIV status" (MacNeil and Anderson 1998:S23). As a result, opportunities to facilitate prevention are lost.

Similarly, care helps people and their families plan for the future, for bereavement, and for the economic security and social arrangements for dependents (MacNeil and Anderson 1998). When secrecy is maintained to avoid discrimination, the lack of planning ultimately leaves orphans and other bereaved dependents economically deprived and often marginalized if the association with HIV becomes known. Poverty is a recognized risk factor for HIV (Beyrer 1998; Somerville and Orkin 1989) and thus the bereaved family members find that their ability to protect themselves from infection is compromised. In some cases, orphans may rely on sex work to meet their immediate financial needs, further increasing their vulnerability to HIV (MacNeil and Anderson 1998). 


\section{Review of Community-level Interventions}

Like other social constructs, stigma and the discrimination that results from it can be challenged and their impact reduced. This paper now turns to describing examples from throughout Southeast Asia where this has occurred. The focus of this review is on community-level interventions, classified by the contexts of discrimination that they address as listed in Table 1 and defined by Malcolm et al. (1998) and others.

\section{Methodology}

Literatures searches were conducted on POPLINE, MEDLINE, and AIDSLINE using a variety of key words related to community-level interventions, stigma and discrimination, attitudes and perceptions of HIV/AIDS in general, and each country of the region. Organizations throughout the region, both governmental and non-governmental, known to be active in community HIV/AIDS work or identified through the literature searches were contacted and interviewed whenever possible; project documents and reports were obtained where available. A request for information was posted on the SEA-AIDS web listing. In addition, a "snowball" recruitment method was used to reach institutions and individuals; all contacted organizations were asked to provide additional contacts.

Approximately half of all contacted organizations provided information for this review. Furthermore, only those interventions considered particularly innovative and relevant to the focus of this paper have been described in detail, with an effort made to include examples from each context of discrimination and as many countries as possible. The comprehensiveness of this review has been limited by difficulties in obtaining a response from contacted organizations, time restraints, and language barriers. Numerous other community-based interventions undoubtedly exist in Southeast Asia that tackle local discrimination in creative and successful ways. Their absence from this review in no way indicates a lack of valuable contributions made on their part.

Most projects identified through this review are not "stigma and discrimination projects" as such. Impact on negative attitudes has frequently been a "side effect" of other goals, or a result of components added when it became apparent that project objectives could not be achieved without paying attention to the barriers posed by pervasive stigma.

The information presented here comes from the "gray literature" of project reports, evaluations, and anecdotal evidence. Indicators of change, again, are generally anecdotal and based on individual perceptions, programmatic experience, and small scale surveys, not scientifically rigorous assessments. In order to begin to systematically and comprehensively address HIVrelated stigma and discrimination, however, the evidence that does exist should be collected and analyzed. It can then serve as an effective base for future initiatives in this important area of the regional response to the epidemic. 
Family/immediate community

\begin{tabular}{|c|c|c|c|}
\hline $\begin{array}{c}\text { Project \& } \\
\text { Country }\end{array}$ & $\begin{array}{l}\text { Mechanism to reduce } \\
\text { discrimination }\end{array}$ & $\begin{array}{l}\text { Other contexts addressed, } \\
\text { if any }\end{array}$ & $\begin{array}{c}\text { Indication of impact on } \\
\text { prevention-to-care } \\
\text { continuum, if any }\end{array}$ \\
\hline $\begin{array}{l}\text { Joint Ministry of } \\
\text { Health/ NGO } \\
\text { Pilot Project on } \\
\text { Home \& } \\
\text { Community Care } \\
\text { for People with } \\
\text { HIV/AIDS } \\
\text { Cambodia }\end{array}$ & $\begin{array}{l}\text { Home visits, counseling, } \\
\text { and demonstration of local } \\
\text { forms of care and treatment } \\
\text { Normalization of casual, } \\
\text { close contact with PHA } \\
\text { Offering services to other } \\
\text { chronically ill patients, not } \\
\text { being a program that is } \\
\text { exclusive or "identifying" } \\
\text { to PHA }\end{array}$ & $\begin{array}{l}\text { Religion: } \\
\text { Mediation with pagodas to } \\
\text { ensure access of PHA to } \\
\text { traditional funeral services } \\
\text { Health services: } \\
\text { Links and referral to local } \\
\text { health providers, both } \\
\text { traditional and state } \\
\text { Media/IEC: } \\
\text { informal education for } \\
\text { family and outreach to } \\
\text { wider community }\end{array}$ & $\begin{array}{l}60 \% \text { families and patients } \\
\text { reported less } \\
\text { discrimination after the } \\
\text { onset of the project. } \\
\text { Outreach and educational } \\
\text { components led to } \\
\text { significant improvements } \\
\text { in understanding on how } \\
\text { to prevent HIV infection. }\end{array}$ \\
\hline $\begin{array}{l}\text { Foundation for } \\
\text { Agricultural and } \\
\text { Rural } \\
\text { Management } \\
\text { (FARM) } \\
\text { HIV/AIDS } \\
\text { Outreach Project } \\
\text { Thailand }\end{array}$ & $\begin{array}{l}\text { Community mobilization } \\
\text { for PHA through income } \\
\text { generation, empowerment } \\
\text { groups, and involvement in } \\
\text { prevention and care } \\
\text { education } \\
\text { Sensitization for other } \\
\text { community members on } \\
\text { living with PHA }\end{array}$ & & $\begin{array}{l}\text { Increased requests to } \\
\text { FARM for help with } \\
\text { sensitizing family } \\
\text { members } \\
\text { Improved willingness to } \\
\text { acknowledge HIV status } \\
\text { to family and community }\end{array}$ \\
\hline $\begin{array}{l}\text { Yayasan Pelita } \\
\text { Ilmu (YPI) } \\
\text { Support Center } \\
\text { and Outreach } \\
\text { Activities } \\
\text { Indonesia }\end{array}$ & $\begin{array}{l}\text { Increase contact with PHA } \\
\text { through creation of a } \\
\text { "buddy system" } \\
\text { Integrate other organized } \\
\text { activities into PHA } \\
\text { community, e.g. holding } \\
\text { meetings of women's } \\
\text { groups, youth associations, } \\
\text { and religious events in the } \\
\text { support center } \\
\text { Conduct practical } \\
\text { demonstrations of care }\end{array}$ & $\begin{array}{l}\text { Religion: } \\
\text { Liaise with community } \\
\text { leaders, including religious } \\
\text { authorities } \\
\text { Media } \\
\text { Advocacy for greater } \\
\text { community acceptance, } \\
\text { e.g. using volunteers to } \\
\text { raise awareness through } \\
\text { contacting local journalists }\end{array}$ & $\begin{array}{l}\text { Perceived greater } \\
\text { community acceptance of } \\
\text { PHA }\end{array}$ \\
\hline $\begin{array}{l}\text { Thai Red Cross } \\
\text { Participatory } \\
\text { Education } \\
\text { Activities } \\
\text { Thailand }\end{array}$ & $\begin{array}{l}\text { Develop curricula that } \\
\text { emphasize that HIV/AIDS } \\
\text { does not differ from other } \\
\text { chronic illnesses in many } \\
\text { symptoms or care needs } \\
\text { Involve PHA in activities, } \\
\text { including peer outreach, to } \\
\text { indicate that PHA can } \\
\text { manage their condition } \\
\text { while fully integrated into } \\
\text { their communities } \\
\text { Participatory life skills } \\
\text { training posits HIV as one } \\
\text { challenge among many } \\
\text { facing Thai communities, } \\
\text { such as the economic crisis, } \\
\text { increase in drug use, etc. }\end{array}$ & $\begin{array}{l}\text { Workplace: } \\
\text { "Friends tell Friends" } \\
\text { program brings curricula } \\
\text { and participatory outreach } \\
\text { to blue and white collar } \\
\text { workers in factories and } \\
\text { other companies (in } \\
\text { collaboration with the Thai } \\
\text { Business Coalition on } \\
\text { AIDS and other partners) }\end{array}$ & $\begin{array}{l}\text { Increase in interest in } \\
\text { volunteerism in } \\
\text { communities, especially } \\
\text { among youth who develop } \\
\text { independent clubs and } \\
\text { care and support projects } \\
\text { Increase in community- } \\
\text { level donations to a } \\
\text { grassroots-funded project } \\
\text { helping to reduce maternal } \\
\text { to child transmission }\end{array}$ \\
\hline
\end{tabular}

Interventions that reduce stigma and discrimination at the level of the family or most immediate community generally rely on outreach activities that actively demonstrate how casual and close contacts do not carry the risk of HIV transmission. The home care teams in Cambodia, for example, visit suspected PHA on a weekly basis and train primary caregivers on how to relieve specific symptoms. By performing treatments in the home that involve touch and close contact with the PHA, the members of the team reinforce their educational messages about what activities do or do not carry risk of transmission (Sarath 1999). Outreach activities from Yayasan Pelita Ilmu's (YPI) Support Center are also informed by the belief that "practical things like waste 
disposal, washing clothes and linen, can best be demonstrated by example" (Djoerban and Djauzi 1998:3). In addition to conducting home visits, volunteers who have been trained as "buddies" operate a book exchange and accompany PHA to public recreational facilities.

Similarly, the FARM outreach project in Thailand responds to requests from PHA to provide training for families and community members on home-based care that will dispel common myths and reduce cases of isolation. They also conduct seminars in villages in the provinces of Phayao, Chiang Mai, and Lampang, where labor migrants return infected from urban areas. These seminars have served to sensitize the community to imminent problems, and recruit the returning PHA into "empowerment groups" that will offer psycho-social support as well as capacitybuilding (Thinwatanangkul 1999).

These interventions also focus on mainstreaming the HIV experience. FARM's income generation schemes (e.g., chicken farms, fish farms, flower wreath arrangement) not only provide financial benefit to PHA and their families, but highlight that PHA can remain economically productive for years. The Thai Red Cross facilitates participatory education techniques that address a wide spectrum of community problems, focusing on how HIV is just one such shared problem. They work with local knowledge that is already present, building on common experience and tradition. Their approach is to refer to the legacy of compassionate family care in Thai society and to point out that in about $98 \%$ of cases, the symptoms experienced by PHA are no different from those of other terminal or chronic illnesses (Carl 1999). The Home Care teams in the Cambodian project contact local traditional healers, school officials, local political leaders, and religious authorities to promote widespread awareness of HIV-related issues (Sellers 1999). YPI also liaises with local leaders and helps to integrate PHA into the normal routines of civil society by encouraging other groups to use the Support Center as a community resource and site for organized activities (Djoerban and Djauzi 1998). This is a particularly innovative strategy as other concerns and interest groups are brought into the PHA's space rather than the other way around.

Almost all of these projects include a prevention education component. After extensive informal outreach efforts by Cambodian Home Care teams, "All participants ... reported that the project had significantly increased understanding on how to prevent HIV infection" (Wells 1999:19). Both the Red Cross and FARM have trained PHA to be facilitators and to diffuse information in a personalized way among their contacts.

Impact on stigma and discrimination is difficult to measure. First, changing attitudes in such intimate contexts can require time, patience, and sustained efforts beyond the time frames of many projects. Second, any perceived outcomes from a given intervention can be confounded by numerous other influencing factors such as the progression of the epidemic within the community or the introduction of new media campaigns. The fact that FARM has noticed increased willingness of PHA to reveal their HIV status or the Red Cross's observation of increases in financial donations and interest in HIV-related volunteerism could spring from the fact that Thailand has suffered an intensive epidemic and few communities or families have remained unaffected. Normalization in some cases is simply due to unusually high prevalence in a given area.

At the same time, however, the epidemic in Cambodia has not yet reached such maturity. The Home Care project conducted a small, quantitative survey after one year of the pilot project. Although instances of extreme discrimination or rejection by families were relatively rare to begin with, some $60 \%$ of project participants noted a decrease in stigma post-intervention (Wells 1999). Similarly, PHA in northern Thailand have specifically sought out FARM's services, indicating that community-based program support does help establish the environment necessary for PHA to feel comfortably integrated in their communities. 
Workplace

\begin{tabular}{|c|c|c|}
\hline $\begin{array}{l}\text { Project \& } \\
\text { Country }\end{array}$ & Mechanism to reduce discrimination & $\begin{array}{l}\text { Indication of impact on prevention- } \\
\text { to-care continuum, if any }\end{array}$ \\
\hline $\begin{array}{l}\text { Thai Business } \\
\text { Coalition on AIDS } \\
\text { (TBCA) } \\
\text { Thailand } \\
\text { Malaysian Business } \\
\text { Coalition on AIDS } \\
\text { (MBCA) } \\
\text { Malaysia }\end{array}$ & $\begin{array}{l}\text { Work with management to implement non- } \\
\text { discriminatory workplace policies } \\
\text { Demonstrate how decreases in } \\
\text { discriminatory measures do not reduce } \\
\text { productivity } \\
\text { Use hierarchical organizational structure to } \\
\text { diffuse attitude change and information } \\
\text { Take advantage of work groups and } \\
\text { "captive audience" in the workplace for } \\
\text { education and awareness raising }\end{array}$ & $\begin{array}{l}\text { Increased interest in activities, for instance: } \\
\text { *ompany managers request PHA to } \\
\text { work with existing staff or visit for } \\
\text { presentations and workshops } \\
\text { Human resources staff ask for technical } \\
\text { assistance for the development of non- } \\
\text { discriminatory policies } \\
\text { Staff volunteer for AIDS NGOs or } \\
\text { specific AIDS projects }\end{array}$ \\
\hline
\end{tabular}

Many HIV projects have begun to address workplace groups. The Thai Business Coalition on AIDS (TBCA) works in partnership with CARE Thailand, the Thai Red Cross, and the Population and Community Development Association, to name a few. The Malaysian Business Coalition on AIDS (MBCA) also coordinates activities with governmental agencies and Malaysian NGOs. The two Coalitions were singled out for mention by this review because of their unusually extensive focus on the workplace context and innovative approaches to mobilizing the private sector.

Both TBCA and MBCA implement similar workplace programs. They have adopted a twopronged approach. First, they target instances of discrimination which occur at the level of workplace policy, such as mandatory testing for applicants or employees and HIV-related dismissal. They hold awareness-raising workshops and use case-studies to demonstrate that PHA remain productive employees for years and that, in fact, respecting human rights ultimately "makes good business sense" (Pramualratana 1999) as it saves constant re-training costs and delays caused by hiring replacements for qualified PHA.

Second, these programs take advantage of the access to large communities that the workplace offers. Existing work groups offer "a captive audience" (Yee 1999) with whom training, workshops, and education sessions can be conducted. Furthermore, addressing the stigma and discrimination that exist within the workplace within the same physical environment helps to connect educational messages to daily reality. Information can also be easily diffused through the hierarchical structures often found in Southeast Asian businesses.

In the future, TBCA and MBCA hope to move into a second phase of activities in which businesses would become more proactive and instigate their own projects and collaborations (Pramualratana 1999). Using their influence and prestige, businesses could sponsor promotional products and events, and encourage employees to take their new knowledge and awareness back to families and communities.

The outlook is positive. Despite initial resistance by business leaders who do not see HIV as a workplace issue, particularly in Malaysia where the epidemic has not yet had significant impact on economic productivity of workforces, interest in such interventions has grown. Human resource managers have requested assistance with drafting policies of nondiscrimination and employees have looked more favorably upon working alongside PHA and have sought additional opportunities to contribute to the response (Yee 1999). The business community remains a valuable, yet still underutilized, resource for inducing widespread change in attitudes regarding HIV/AIDS. 
Health services

\begin{tabular}{|c|c|c|}
\hline $\begin{array}{c}\text { Project \& } \\
\text { Country }\end{array}$ & Mechanism to reduce discrimination & $\begin{array}{l}\text { Other contexts addressed, } \\
\text { If any }\end{array}$ \\
\hline $\begin{array}{l}\text { Hope Foundation } \\
\text { Philippines }\end{array}$ & $\begin{array}{l}\text { Seminars and training sessions conducted } \\
\text { for health personnel in municipal and } \\
\text { private hospitals } \\
\text { Design of curricula and IEC material for } \\
\text { students/ new health personnel } \\
\text { Form support links with health providers to } \\
\text { offer technical assistance/information when } \\
\text { they come across PHA among their patients }\end{array}$ & $\begin{array}{l}\text { Established AIDS Council to create a broad } \\
\text { network composed of organizations from all } \\
\text { sectors of civil and governmental society, e.g.: } \\
\text { religious agencies } \\
\text { academic institutions } \\
\text { outreach counseling projects } \\
\text { labor groups }\end{array}$ \\
\hline $\begin{array}{l}\text { Wednesday } \\
\text { Friends' Club } \\
\text { Thailand }\end{array}$ & $\begin{array}{l}\text { Development of activity to empower PHA } \\
\text { in their health-seeking behavior } \\
\text { Production of "factsheets" that will address } \\
\text { topics such as traditional care and new } \\
\text { medical advances and will encourage PHA } \\
\text { to be proactive in dealing with health } \\
\text { services }\end{array}$ & $\begin{array}{l}\text { As an empowerment group, the Wednesday } \\
\text { Friends' Club also discusses experiences of } \\
\text { discrimination in any context, as brought up } \\
\text { by members. }\end{array}$ \\
\hline
\end{tabular}

Discrimination experienced within the health sector can prevent PHA from seeking care if they feel they will receive an unwelcome reception or that their confidentiality will not be respected (Malcolm et al. 1998). Furthermore, the expectation of such treatment from service points may reduce the number of individuals choosing to be tested. Sensitivity of health providers toward PHA remains a critical requisite of effective medical services within the response to HIV/AIDS.

At the very least, health personnel need a thorough understanding of how HIV is transmitted, familiarity with universal precautions, knowledge of locally available models of care, and awareness of the importance of confidentiality. Ideally, health providers should have a grounding in counseling and support skills, an appreciation for the wider socio-cultural issues related to HIV, and the ability to refer PHA to a variety of psycho-social, welfare, and care services.

In the Negros Occidental province of the Philippines, HIV is not widespread. As a result, health workers without much exposure to PHA have often reacted with fear to new patients. The Hope Foundation project has targeted service providers and new professionals in the field and has made materials available to them in local dialects. In addition to seminars and training, the Hope Foundation provides ongoing support and technical assistance to both governmental and private providers as they increasingly encounter PHA patients (Hope Foundation 1999). Through their participation in the multisectoral AIDS Council which maintains active links with 37 other institutions, the Hope Foundation is tackling barriers of discrimination from the early stages of the epidemic, and in a way that moves considerably beyond the provision of medical information.

A different approach to changing the medical establishment's reaction to HIV is to strengthen the capacity of PHA to seek appropriate care. The Thai Red Cross is initiating a new activity through its Wednesday Friends' Club, a support and empowerment program for PHA (Carl 1999). In the coming year or so, PHA will develop a series of factsheets on a range of topics. The focus, however, will be on challenging traditional views of health services as an "Ivory Tower." PHA will be encouraged to become involved in their own treatment. Requesting additional information, keeping informed about available options, and taking an active rather than passive role in interactions with medical personnel will be emphasized as critical in the same way that adherence to drug regimens has been. 


\begin{tabular}{|c|c|c|c|}
\hline $\begin{array}{l}\text { Project \& } \\
\text { Country }\end{array}$ & $\begin{array}{l}\text { Mechanism to reduce } \\
\text { discrimination }\end{array}$ & $\begin{array}{l}\text { Other contexts addressed, } \\
\text { if any }\end{array}$ & $\begin{array}{c}\text { Indication of impact on } \\
\text { prevention-to-care } \\
\text { continuum, if any }\end{array}$ \\
\hline $\begin{array}{l}\text { Islam and } \\
\text { HIV/AIDS, } \\
\text { Malaysian } \\
\text { AIDS } \\
\text { Council } \\
\text { Malaysia }\end{array}$ & $\begin{array}{l}\text { Sensitize religious community } \\
\text { to discrimination experienced } \\
\text { by PHA } \\
\text { Form partnerships to recruit } \\
\text { religious leaders (Mufti) into } \\
\text { activism for HIV-related human } \\
\text { rights }\end{array}$ & & $\begin{array}{l}\text { After initial 2-day } \\
\text { workshop, muftis } \\
\text { spontaneously formed a } \\
\text { working committee } \\
\text { Agreement reached on } \\
\text { groundbreaking } \\
\text { resolutions, e.g., } \\
\text { acceptance of harm } \\
\text { reduction as an appropriate } \\
\text { strategy }\end{array}$ \\
\hline $\begin{array}{l}\text { Sangha } \\
\text { Metta } \\
\text { Project } \\
\text { Thailand }\end{array}$ & $\begin{array}{l}\text { Mobilize Buddhist monks to } \\
\text { accept a role in community } \\
\text { response to HIV/AIDS } \\
\text { High profile care activities } \\
\text { demonstrating compassion and } \\
\text { dispelling myths about casual } \\
\text { contact } \\
\text { Ensuring that PHA can } \\
\text { maintain a spiritual life and } \\
\text { receive traditional funeral rites }\end{array}$ & $\begin{array}{l}\text { Family/Immediate } \\
\text { community: } \\
\text { Monks conduct home visits } \\
\text { and demonstrate care. } \\
\text { Conduct awareness-raising } \\
\text { events within community. } \\
\text { Provide housing for male } \\
\text { orphans } \\
\text { Media/IEC: } \\
\text { Advertise "HIV-friendly } \\
\text { temples" to promote } \\
\text { community integration of } \\
\text { PHA. } \\
\text { Broadcast presentations by } \\
\text { PHA or temple discussions } \\
\text { with loudspeakers to } \\
\text { extended community }\end{array}$ & $\begin{array}{l}\text { After events, local } \\
\text { individuals contact } \\
\text { services and are willing to } \\
\text { disclose their status or } \\
\text { admit there are PHA in } \\
\text { their families } \\
\text { Increase in interest in } \\
\text { established community } \\
\text { HIV network }\end{array}$ \\
\hline
\end{tabular}

While many outreach projects that diffuse their messages through revered members of the community help reduce stigma against PHA, when such encouragement comes from spiritual leaders, the impact can be significantly greater as it carries the additional authority of an accepted ethical system.

To a large extent the monks of the Sangha Metta Project provide many of the same basic services as other home-based care and support programs: "They set an example by visiting PHA in their community, setting up meditation training for them, vocational training activities and inviting PHA to assist with work and other activities in the temple" (Maund 1999). They also give welfare assistance and help ensure that bereaved families will be able to afford traditional burials. Yet for "... the HIV/AIDS patients and their families, what is more important than material support is perhaps the moral embrace offered by those they highly respect" (Sukrung 1999).

Similarly, the Malaysian AIDS Council managed to gain the support of the Minister for Islamic Affairs for its activities and 9 out of 14 state religious authorities (Mufti) attended the initial workshop (Selveratnam 1999). After attending discussions that combined technical information, presentations by PHA Muslims, and philosophical debates about HIV and the Koran, religious authorities in Malaysia initiated their own working groups to continue investigating the issues raised. The next step will be to operationalize the partnership formed with the Islamic community by involving the Mufti in program design, with guidance from "lessons learned" through the renowned Ugandan program with Imams. The Ugandan project developed mobilization and support strategies among religious networks to involve Imams and other volunteers in prevention and advocacy work (UNAIDS 1998). 


\begin{tabular}{|c|c|c|}
\hline Country & Public Event/ IEC Campaign & Mechanism to reduce discrimination \\
\hline Cambodia & $\begin{array}{l}\text { Prince Ranariddh gives flowers to a PHA at } \\
\text { National AIDS Conference and is } \\
\text { photographed with his arm around her }\end{array}$ & $\begin{array}{l}\text { Active demonstration of compassion, close } \\
\text { contact, and lack of stigma by influential public } \\
\text { figure }\end{array}$ \\
\hline Vietnam & $\begin{array}{l}\text { Documentation and dissemination of in-depth } \\
\text { interviews in the form of life histories (CARE- } \\
\text { Vietnam) }\end{array}$ & $\begin{array}{l}\text { Illustration of a wide variety of experiences and } \\
\text { emotions, personalization of HIV }\end{array}$ \\
\hline Thailand & $\begin{array}{l}\text { Sponsorship of a float in a traditional Loy } \\
\text { Krathong Festival parade featuring a PHA } \\
\text { beauty queen, children of PHA, and public } \\
\text { announcement of their HIV status and how to } \\
\text { join community networks (Sangha Metta } \\
\text { Project). }\end{array}$ & $\begin{array}{l}\text { Integration of HIV issues and PHA into } \\
\text { traditional cultural activities; normalization of } \\
\text { disease and demonstration of acceptability of } \\
\text { disclosing status }\end{array}$ \\
\hline Lao PDR & $\begin{array}{l}\text { Production of an interactive educational video, } \\
\text { "Let's learn about HIV/AIDS/STD" by the } \\
\text { Lao Red Cross. }\end{array}$ & $\begin{array}{l}\text { Use of three stories, including an example of } \\
\text { dealing with HIV directly in the community, to } \\
\text { stimulate thought about hypothetical but } \\
\text { realistic situations and emphasize respect and } \\
\text { compassion }\end{array}$ \\
\hline
\end{tabular}

Early publicity campaigns throughout the region emphasized the dangers of HIV and the inevitability of death, reinforced existing gender stereotypes, and focused on the vilification of "core transmitters" such as SW (Lyttleton 1996). The prevalence of these themes prompted two authors to state "As a result, HIV and AIDS are perhaps even more stigmatized in Asia and the Pacific than in other parts of the world" (Tan and Brown 1994).

In later years, however, efforts to redress the damage of the original public health messages have emerged in force. Meechai Viravaidya, a prestigious member of Thai society and Chair of the Population and Community Development Association, began sitting down to meals with PHA and their family members in the presence of the press quite early in the epidemic. In recent months, the Bangkok Post ran a series of articles about the negative impact of discrimination. At the First National Conference on HIV/AIDS in Cambodia, Prince Ranariddh posed for photographers with his arm around a PHA who had opened the proceedings with a narration of her family's experience with HIV and community discrimination. The monks of the Sangha Metta Project took advantage of their already well-recognized publicity to sponsor an HIV-themed parade float, transforming a cultural symbol into a high-profile statement of tolerance. All of these actions reinforce an increasingly prevalent message: HIV is a shared concern that can be "incorporated into everyday issues rather than separated out as a special, often inappropriate issue" (Thai Red Cross 1999).

CARE-Vietnam's set of booklets documenting the life histories of PHA goes beyond most information campaigns and quite explicitly targets community-level stigma. The in-depth interviews in Will to Live (Nguyen and Nguyen 1996) and If Only... (Nguyen 1997) are presented in both Vietnamese and English. The interviews encouraged interpretation by the PHA themselves, who offer a wide diversity of experiences. They highlight the extenuating circumstances and socioeconomic trends that have put people at risk of infection, such as extreme poverty, traditional responsibilities to support older family members, and gender relations in Vietnamese society. These intensely personalized examples, as well as the addition of thoughtprovoking "discussion questions," ensure that the books encourage a multidimensional approach to HIV and stay clear of simplistic associations that have characterized the "social evils" campaign. Furthermore, the inclusion of information sections summarizing a range of technical and social issues make these publications valuable educational tools for both prevention and care. The Lao Red Cross's use of an interactive video for training projects also helps to raise awareness by providing the audience with "...the opportunity to imagine what it would be like, how they would act, if they met someone with HIV, and models a supportive attitude" (Nierras 1999). 


\section{Conclusion: The Way Forward}

Despite the fact that the reviewed projects have been implemented in different countries and have used a wide diversity of approaches, they nonetheless share certain components worth illuminating. These common attributes, described below, deserve sustained focus in future activities. What unifies these shared characteristics is their emphasis on process which means that they can be integrated into numerous approaches to HIV/AIDS, and indeed mainstreamed into basic community development projects. Specifically targeting HIV-related stigma and discrimination, therefore, proves less crucial than how activities and interventions are conducted. More research is required, however, to ensure that the response can become increasingly refined in future.

\section{Participation of PHA}

"The increased visibility of people with the disease in the community can result in greater community acceptance and support" (Malcolm et al. 1998:364). This kind of increased community contact with PHA can occur in advanced stages of the epidemic, such as in northern Thailand, where almost every family has been directly affected by HIV. But it can also occur in any situation where PHA are brought to the forefront of the response and are involved in all stages of interventions. A positive cycle thus comes into effect: as PHA become active members throughout society, stigma against them is reduced, and consequently, this reduction in discrimination encourages more people to publicly identify themselves as HIV-positive.

Almost all the interventions highlighted in this review rely heavily on the participation of PHA who thus "lobby their cause from a first-person point of view" (Selveratnam 1999). PHA facilitate activities in the workplace, they give presentations to religious leaders, organize empowerment groups, advocate for change in how they are treated by families or health providers, and promote prevention by personalizing their experiences for others. By delegating central responsibilities to PHA, programs further emphasize the message that PHA can continue to lead productive lives and contribute to the development of their communities.

At the most developed end of the spectrum, PHA involvement can evolve into proactive activism. The way in which the Wednesday Friends' Club in Thailand is increasingly mobilizing its members to take control over the process of challenging discrimination is one example of this kind of empowerment. Similarly, other PHA organizations such as Access, also in Thailand, a "Friends Help Friends" self-help group in Danang, Vietnam, and Suryakanta in Bali, all manage their own activities, refer PHA to other available services, and plan, design, and implement new initiatives depending on emerging needs. These ongoing networks, although not mentioned in the review as specific "projects," are clear examples of sustainable efforts on the part of PHA to reduce discrimination levelled against them.

Encouraging and nurturing PHA networks and groups, therefore, is a crucial first step for projects to consider. Helping PHA to break down their sense of isolation, develop a safe social space for themselves, and then learn from each other, gain strength, and identify priorities as a group can begin the process of normalizing their presence within a community. One untapped resource for such activity may be the "virtual community" offered by the internet. Information technology is increasingly available to large groups of people, is confidential, and allows for networking and discussion by people who might otherwise not have geographical access to one another. Existing PHA networks might be able to reach a wider audience with their information, services, and advocacy at little additional cost by using this new medium to help break down social barriers.

\section{Addressing the whole continuum}

The idea that prevention and care lie along a continuum and must be addressed as such has increasingly gained credence. Because the epidemic operates as a cycle within a community, and because stigma poses barriers along this same cycle, it follows that the most effective interventions will target discrimination at different stages simultaneously. Many of the programs reviewed do consider the ways in which discrimination hinders both prevention and care-seeking. 
The Thai Red Cross curricula, for instance, uses a participatory "facts for life" approach to teach negotiation skills for risky situations, alongside promoting involvement in local care.

Using the same processes, the workshops run by the Thai and Malaysian Business Coalitions on AIDS help workers understand how to prevent acquisition of HIV and how to continue working alongside their PHA colleagues without fear or loss of productivity. Religious leaders in Malaysia formally acknowledged their role in both supporting harm reduction measures and creating supportive environments that will encourage Muslim PHA to admit their status and seek care and support.

Another approach could use care and support activities as a prevention-education tactic. Involving volunteers, particularly young people, as home-care visitors, "buddies," and training them extensively in "hands-on" support techniques will expose them to PHA and the issues surrounding HIV/AIDS. This intensive face-to-face contact may serve to reduce the isolation of PHA and limit the stigma and discrimination that often result from fears of close contact. At the same time, it could stimulate reflection of vulnerability and risk, forcing the volunteers to confront HIV as a problem that affects their community and themselves. This realizationthrough-action could reinforce messages of behavior change and risk-reduction in a way that education alone cannot. An operations research study conducted by HORIZONS in Africa is currently underway that will assess such a combined care and prevention strategy.

\section{Integrating contexts}

In the same way that individuals are members of a number of "communities" throughout their lives, projects do well to look beyond any one context of discrimination. The Hope Foundation's networking and capacity-building efforts throughout society serve as an excellent example of such a comprehensive community-based approach.

Even activities that focus on one context of discrimination almost exclusively can still strengthen their impact by acknowledging links with other social arenas. The Sangha Metta Project integrates a variety of community approaches in a holistic way. It maintains a high-profile public image through media-friendly events, uses religious authorities as promoters of compassion, and has monks serve as community outreach workers to demonstrate care activities to families. The Home Care Teams in Cambodia similarly build networks between family care and formal sector service providers, religious leaders, schools, and PHA.

Ultimately the model should move toward more comprehensive integration. As HIV/AIDS increasingly impact the development of countries, a growing number of development agencies have incorporated HIV/AIDS work into their mandates. Non-health-related NGOs find that their areas of expertise have in some way been affected by the epidemic and that they cannot afford to "compartmentalize" HIV away from community development overall. Any organization or institution can address the relevant HIV/AIDS issues within its activities. Although this can be seen as a vague recommendation, the specific message in terms of stigma and discrimination is that a multipronged attack will most likely have the biggest impact. Most of the projects in this review come from organizations primarily focused on the AIDS problem. As mentioned, their success in challenging community-level discrimination has deepened through increasing the number of target contexts. The corollary of this finding is that other organizations, whether they address economics, education, the environment or any other developmental issue, will also significantly contribute to this effort by adding AIDS to their agenda and contributing their specific strengths from other contexts. The role for HIV-focused projects in this regard, therefore, is to provide information, technical assistance, networking links, and policy advocacy to facilitate such a broad-based and integrated approach to reducing stigma in the community.

\section{Implications for future research}

Surveying the anecdotal evidence, as this review has attempted to do, can serve as a base upon which to build future efforts. Clearly a wide variety of approaches and opportunities exist to counteract the negative influence of HIV-related stigma and discrimination. Lessons from the past do highlight ways forward. 
However, additional, rigorous data are needed to identify the exact mechanisms in greater detail that help reduce stigma and discrimination. A positive step would be the development of widely accepted indicators to measure changes in stigmatizing attitudes. These could then be applied to operations research studies even in cases where the primary area of investigation is not directly related to reducing discrimination. Finally, evaluation and monitoring structures should track trends in this important area throughout the implementation phases of various projects, perhaps using the same indicators adapted to the specific situation. By considering levels and forms of stigma and discrimination throughout the response to the epidemic, the chances of understanding these social constructs would improve. Consequently, so would the ability to counteract them. 


\section{Bibliography}

Alonzo, Angelo and Nancy Reynolds. 1995. "Stigma, HIV and AIDS: An exploration and elaboration of a stigma trajectory." Social Science and Medicine 41(3): 303-315.

APN+. 1999. "A multi-city participatory action research on AIDS and human rights in Asia Pacific region." Report. pp. 1-9.

Assavanonda, Anjira. 1999. "Future bleak for young victims." Bangkok Post. May $31^{\text {st }}$.

Assavanonda, Anjira and Onnucha Hutasingh. 1999. "HIV victims remain pariahs in rural communities." Bangkok Post. September $28^{\text {th }}$.

Bentley, Margaret, Kai Spratt, Mary Shepherd, Raman Gangakhedkar, S. Thilikavathi, Robert Bollinger, and Sanjay Mehendale. 1998. "HIV testing and counseling among men attending sexually transmitted disease clinics in Pune, India: Changes in condom use and sexual behavior over time." AIDS 12(14): 1869-1877.

Beyrer, Chris. 1998. War in the Blood: Sex, Politics and AIDS in Southeast Asia. London: Zed Books.

Bhatiasevi, Aphaluck. 1999. "Orphans ostracised by their community." Bangkok Post. June $28^{\text {th }}$.

Bunting, Sheila. 1996. "Sources of stigma associated with women and HIV." Advanced Nursing Science 19(2): 64-73.

Carl, Greg. 1999. Telephone interview. August $31^{\text {st }}$.

Da Nang AIDS Committee and World Vision. 1998. Conference on Health Care and Social Support for People Living with HIV/AIDS. Report. December.

De Zoysa, I., K. Phillips, M.C. Kamenga, Kevin O’Reilly, M. Sweat, R. White, O. Grinstead, and Thomas Coates. 1995. "Role of HIV counseling and testing in changing risk behavior in developing countries." AIDS 9(Suppl 2): S95-S101.

Djoerban, Zubairi. 1998. "Disguised practice: Stigmatization, isolation and discrimination of the HIV-infected person," paper presented at the HIV/AIDS ASEAN Regional Workshop of Islamic Religious Leaders in Jakarta, November 30 -December 3.

Djoerban, Zubairi and Samsuridjal Djauzi. 1998. "Yayasan Pelita Ilmu and support activities," paper presented at the HIV/AIDS ASEAN Regional Workshop of Islamic Religious Leaders in Jakarta, November 30 -December 3.

Gilmore, Norbert and Margaret Somerville. 1994. "Stigmatization, scapegoating and discrimination in sexually transmitted diseases: Overcoming 'them' and 'us." Social Science and Medicine 39(9): 1339-1358.

Goldin, Carol. 1994. "Stigmatization and AIDS: Critical issues in public health." Social Science and Medicine 39(9): 1359-1366.

Gruskin, Sofia, Aart Hendriks, and Katarina Tomasevski. 1996. "Human rights and responses to HIV/AIDS," in AIDS in the World II, ed. Jonathon Mann and Daniel Tatantola. New York: Oxford University Press, pp. 326-340.

Herek, Gregory and Eric Glunt. 1988. "An epidemic of stigma: Public reactions to AIDS." American Psychologist 43(11): 886-891.

Hope Foundation. 1999. Telephone interview. September $1^{\text {st }}$.

Insisiengmay,Sithat and Khathong Bounlu. 1998. "Laos," in Sexually Transmitted Diseases in Asia and the Pacific, ed. Tim Brown, Roy Chan, Doris Mugrditchian, Brian Mulhall, David Plummer, Rabin Sarda, and Werasit Sittitrai. Armidale, Australia: Venereology Publishing, pp. 150-160. 
Kegeles, Susan, Thomas Coates, T. Anne Christopher, and Jeffrey Lazarus. 1989. "Perceptions of AIDS: The continuing saga of AIDS-related stigma." AIDS 3(Suppl 1): S253-S258.

Lyttleton, Chris. 1996. "Messages of distinction: The HIV/AIDS media campaign in Thailand." Medical Anthropology 16: 363-389.

MacNeil, Joan and Sandra Anderson. 1998. "Beyond the dichotomy: Linking HIV prevention with care." AIDS 12(Suppl 2): S19-S26.

Malcolm, Anne, Peter Aggleton, Mario Bronfman, Jane Galvao, Purnima Mane, and Jane Verrall. 1998. "HIV-related stigmatization and discrimination: Its forms and contexts." Critical Public Health 8(4): 347-370.

Maund, Lawrence. 1999. Personal communication. July $30^{\text {th }}$.

McGrath, Janet. 1992. "The biological impact of social responses to the AIDS epidemic." Medical Anthropology 15: 63-79.

Miller, Heather, Charles Turner, and Lincoln Moses (eds.). 1990. AIDS: The Second Decade. Washington: National Academy Press, pp. 115-127.

Misra, Sujaya. 1999. "Social discrimination and rejection in Cambodia." SEA-AIDS Discussion Forum: 2040 (http://www.hivnet.ch:8000/sea-aids/msg2040).

Nguyen, Nguyen Nhu Trang. (ed.) 1997. If Only .... Vietnam: CARE International.

Nguyen, Nguyen Nhu Trang and Nguyen Thi Oanh. (eds.) 1996. Will to Live. Vietnam: CARE International.

Nierras, Ted. 1999. Personal communication. September $13^{\text {th }}$.

Phuah, Phaik-Choo. 1999. "Discrimination and human rights in Cambodia." SEA-AIDS

Discussion Forum: 2037 (http://www.hivnet.ch:8000/sea-aids/msg2037).

Pramualratana, Anthony. 1999. Telephone interview. August $31^{\text {st }}$.

Sarath, Chhim. 1999. Interview. August $3^{\text {rd }}$.

Sarjana, I.G.P., I.B. Wiyadnyana, and Yayasan Kauci. 1999. "Reception of people with HIV/AIDS by health care providers and by the community. A qualitative study on social discrimination experienced by people with HIV/AIDS (ODHA) in Bali." Unpublished.

Sellers, Tilly. 1999. Interview. August $3^{\text {rd }}$.

Selveratnam, Joe. 1999. Telephone interview. August $27^{\text {th }}$.

Somerville, Margaret and Andrew Orkin. 1989. "Human rights, discrimination and AIDS: Concepts and issues." AIDS 3(Suppl 1): S283-S287.

Stephens, David, Geoffrey Woolcock, Dennis Altman, and Teresita Bagasao. 1998. "Conflict and consensus: HIV/AIDS and human rights in Asia and the pacific." AIDS 12(Suppl B): S93-S99.

Sukrung, Karnjariya. 1999. "Leading the way." Bangkok Post. August $3^{\text {rd }}$.

Tan, Michael and Tim Brown. 1994. "Social policy, human rights, and HIV/AIDS in Asia and the Pacific.” AIDS 8(Suppl 2): S207-S213.

Thai Red Cross. "Life Skills Development for Behavior Change." AIDS Research Center Publication.

Thinwatanangkul, Supaporn. 1999. Telephone interview. September $1^{\text {st }}$.

UNAIDS. 1998. AIDS Education through Imams: A Spiritually Motivated Community Effort in Uganda. (Best Practice Case Study) Geneva: UNAIDS.

Ungphakorn, Jon and Werasit Sittitrai. 1994. "The Thai response to the HIV/AIDS epidemic." AIDS 8(Suppl 2): S155-S163. 
Weinhardt, L., M. Carey, B. Johnson, and N. Bickham. 1999. "Effects of HIV counseling and testing on sexual risk behavior: A meta-analytic review of published research, 1985-1997." American Journal of Public Health 89(9): 1397-1405.

Wells, Henrietta. 1999. Joint Ministry of Health/NGO Pilot Project on Home and Community Care for People with HIV/AIDS. Report 1998-1999. Phnom Penh: KHANA.

Yee, Khim Chong. 1999. Telephone interview. August $25^{\text {th }}$. 